\title{
Focus Issue Articles on Emerging and Re-Emerging Plant Diseases
}

\author{
Krishna V. Subbarao, George W. Sundin, and Steven J. Klosterman
}

First author: University of California, Davis, c/o U.S. Agricultural Research Station, 1636 E. Alisal Street, Salinas, CA 93905; second author: Michigan State University, East Lansing, MI 48824; and third author: U.S. Department of Agriculture-Agricultural Research Service, 1636 E. Alisal Street, Salinas, CA 93905.

The history of plant pathology is closely tied to plant diseases that have changed the course of human history. The Irish potato famine, caused by late blight of potato, resulted in the starvation and death of millions of people and one of the most influential human migrations in history. Other plant diseases have impacted quality of life in myriad ways. The advent of fungicides, clean seeds, host resistance, and the development of a plethora of other techniques, has diminished the impact of plant diseases. However, impressive advances in modes of rapid transport have not only increased global trade and human migration, but also augmented the risk for anthropogenic invasions of plant pathogens. As a consequence, and possibly aggravated by climate change, many historical and contemporary diseases are emerging as threats to modern agriculture and food security. These emerging diseases are not only important in global crop production, but also pose severe risks on a local level, especially on small farms in developing countries. This Focus Issue of Phytopathology contains a collection of peerreviewed research articles, invited reviews and perspective articles on an assortment of emerging and re-emerging diseases caused by bacterial (3 papers), fungal (6 papers), oomycete (5 papers), and viral plant pathogens ( 3 papers). These diseases cover a range of crops including annual field crops and perennial tree crops, and vegetables, across five continents. The following are brief summaries of the papers appearing in this issue.

\section{DISEASES CAUSED BY BACTERIA}

The first of the two articles on zebra chip of potato, which was first identified in the mid-1990s in Mexico, and now is present in Central and North America and in New Zealand, Rush et al. (2015) explore the impact of late-season infections on storage of potatoes. Severe epidemics occurred in the southwestern United States in the mid-2000s. The putative causal agent of zebra chip is a phloemlimited nonculturable bacterium, 'Candidatus Liberibacter solanacearum' (CLso), that is vectored by the potato psyllid. Management of zebra chip is focused on insecticide applications, which are typically terminated 2 to 3 weeks before harvest. Rush et al. (2015) show that late-season infections occurring 1 week or less before harvest can lead to significant issues for storage, export, and seed production. Their work also addresses questions concerning the potential role of migrating psyllids in transmitting the pathogen at a regional level, and environmental factors influencing the disease.

Thompson et al. (2015) investigated two of the five haplotypes of CLso. They obtained draft genome sequences for haplotype A isolates from New Zealand and from Texas, and compared these sequences with a haplotype B isolate from Texas. Haplotype A isolates appear to have lower virulence compared with haplotype B.

Corresponding author: K. V. Subbarao; E-mail address: kvsubbarao@ucdavis.edu

http://dx.doi.org/10.1094/PHYTO-105-7-0001

(C) 2015 The American Phytopathological Society
The authors identified 46 distinct genetic loci present in haplotype $\mathrm{A}$ and speculated that the genetic variation observed within CLso isolates is the determinant of zebra chip symptom differentiation between potatoes grown in New Zealand and Texas.

In the third article on bacteria, Oliver et al. (2015) determined that Xylella fastidiosa isolates from both the subspecies multiplex and fastidiosa can cause blueberry leaf scorch under greenhouse conditions. Although currently only X. fastidiosa subsp. multiplex isolates have been recovered from infected blueberry plants in the southeastern United States, X. fastidiosa subsp. fastidiosa occurs commonly on infected grapevine in this region. These authors (Oliver et al. 2015) demonstrated the potential of $X$. fastidiosa subsp. fastidiosa as a blueberry pathogen, and identified the differences in interactions of blueberry with $X$. fastidiosa subsp. multiplex and $X$. fastidiosa subsp. fastidiosa that could be helpful in the deployment of host resistance as a control strategy.

\section{DISEASES CAUSED BY FUNGI}

Stem rust of wheat, caused by Puccinia graminis f. sp. tritici, is among the most important threats to food security and has historically been a major disease of wheat worldwide. The disease was successfully managed using host resistance with either single or combinations of $\mathrm{Sr}$ (stem rust) genes. However, race Ug99, which was first detected in Uganda in 1998, carries new virulence traits and is threatening wheat production and global food security. Singh et al. (2015) review the current status of the Ug99 race group (TTKSK, TTKST, TTTSK, and TTKSF), its spread, and new strategies for the successful management of stem rust caused by strains in the Ug99 group.

Another article, by Olivera et al. (2015), documents the intense breeding efforts in response to races of the Ug99 lineage and how they led to the successful deployment of wheat cultivars with resistance to these races. In Ethiopia, the largest wheat producer in sub-Saharan Africa, the extensive losses caused by stripe rust in 2010 have provided an added incentive for growers to adapt these new cultivars with resistance to different rusts coupled with high yield. The most widely grown hexaploid wheat cultivar, Digalu, in Ethiopia suffered near-total yield losses in southern Ethiopia in 2013. Olivera et al. (2015) characterized strains collected from these epidemics and identified a new race, TKTTF, which is genetically distinct from the Ug99 lineage. Appearance of this new race underlines the continuing threats and challenges posed by stem rust to wheat production.

Soybean rust, caused by Phakopsora pachyrhizi, struck fear into soybean growers in the continental United States long before its eventual arrival in Louisiana in 2004. An unprecedented effort was mounted against the disease involving multiple research groups that surveyed the movement of soybean rust within the continental United States and studied other aspects of the disease. Details are provided by Kelly et al. (2015), who also summarize the latest in soybean rust research, including epidemiology and efforts to breed resistant soybean. The results over the past decade led to effective pathogen monitoring and management of the disease. 
Applying a broader perspective, Sanatkar et al. (2015) illustrates concepts important for the analysis of emerging diseases, using the annual U.S. soybean rust invasion as an example. Ecological history, such as the particular pathogen genotypes that reach North America, must be understood to evaluate future risks. Model burnin, which is the improvement of a model as more data become available, may be an on-going process due to changing epidemics. Epidemic evolution, through factors such as climate change or deployment of new disease resistance genes, may decrease the lifespan of models constructed using older data. And evaluations of epidemic risk must find an appropriate weighting for the importance of false positive and false negative predictions.

Havis et al. (2015) provide a detailed accounting of the epidemiology of Ramularia collo-cygni, an emerging fungal pathogen of barley (Hordeum vulgare). The disease caused by $R$. collo-cygni, also known as Ramularia leaf spot, is occurring with increasing frequency. More recently, molecular diagnostic tools have enabled detection and identification of $R$. collo-cygni. The authors describe efforts in understanding pathogen, host genetics, and management approaches to reduce yield losses caused by Ramularia leaf spot.

Another important crop, sunflower, has recently been affected by two fungal species, Diaporthe helianthi and D. gulyae, the causal agents of stem canker (Mathew et al. 2015). Mathew et al. (2015) established that the two species are responsible for Phomopsis stem canker on sunflowers in the United States. Previously, only $D$. helianthi had been identified in the United States. Even though it appears that emergence of a new Diaporthe pathogen in the United States may have contributed to the recent increases in Phomopsis stem canker in the Northern Great Plains, the authors caution against this scenario, and instead point to heightened awareness and reporting of the problem. Cultural practices, such as increased production of sunflowers on no-till and minimum till production systems, may also have played a role.

\section{DISEASES CAUSED BY OOMYCETES}

Late blight of potato is regarded as the most devastating disease of potatoes. It is caused by the pathogen Phytophthora infestans, and the disease is as old as the development of plant pathology as a science. The question then is why is late blight an emerging plant disease? Fry et al. (2015) provide convincing arguments for its continued importance due to regular emergence of novel strains of $P$. infestans with increased virulence, its appearance in new locations with surprising intensity, and $P$. infestans serving as a model system to study determinants of pathogenicity at the molecular level. Overall, the authors provide a comprehensive review of the current population biology and the recent knowledge acquired through molecular genetic analyses. Fry et al. (2015) suggest that recently developed rapid diagnostic tools and genotyping technologies will soon have an impact on the development of improved management strategies.

Another important oomycete disease, sudden oak death caused by $P$. ramorum, was first discovered in the mid-1990s on coastal live oaks and tanoaks in California, and has now spread to Oregon. The disease was first discovered in Oregon during aerial surveys in 2001. Two papers are published on sudden oak death in this issue. In the first, Kamvar et al. (2015) characterized the pathogen population collected since 2001 using microsatellite markers, and found that a single clonal lineage dominates this population. They trace this lineage to nursery plants from either California or from other parts of Oregon and recommend eradication of the symptomatic trees as soon as the disease is discovered. In a second paper, by Peterson et al. (2015), a modeling approach was employed to determine the annual variation in epidemic severity, dispersal distance, and the size of infected areas. Results from the modeling suggested that the maximum dispersal distances were influenced by spring and winter precipitation 2 years prior to detection, and infestation size during the previous year. Infestation size depended on spring precipitation and infestation size during the preceding year. The model was then validated with data collected from a site in Oregon. The eradication program in Oregon has not eliminated the pathogen but has slowed the epidemic, demonstrating its usefulness.

The downy mildews, another important group of oomycete pathogens, are major diseases of many crops, including vegetables. Similar to the diseases caused by Phytophthora spp., downy mildews are also major re-emerging diseases in many crops. Cohen et al. (2015) focus on the cucurbit downy mildew pathogen Pseudoperonospora cubensis, including the recent appearance of aggressive new races in the United States and other countries and of new mating types worldwide. They also review potential reasons for the re-emergence of this pathogen. These include infections arising from oospores, and the long-distance dispersal of new races and mating types of $P$. cubensis. New evidence also indicates that the seedborne nature of $P$. cubensis is an additional avenue of distributing virulent strains.

Within the past decade, global production of sweet basil has increased but is threatened by another downy mildew pathogen, Peronospora balbahrii. Approaches to minimize losses associated with the emergence of basil downy mildew have been complicated by a lack of genetic resistance in basil and also by worldwide dispersal of the pathogen on seed. Wyenandt et al. (2015) describe the current system used to monitor the pathogen, efforts to develop host resistance, and fungicide usage for disease control.

\section{DISEASES CAUSED BY VIRUSES}

Several diseases caused by plant viruses have recently emerged to cause economic losses. Three diseases caused by new or reemerging viruses in maize, grape, and citrus are highlighted here. In the first article, Mahuku et al. (2015) discuss an emerging threat to maize in sub-Saharan Africa known as maize lethal necrosis (MLN), a disease caused by a synergistic coinfection with Maize chlorotic mottle virus (MCMV) and one of three other potyviruses. Mahuku et al. (2015) summarize the current status of this disease problem in Kenya, Rwanda, and the Republic of Congo and indicate that Sugarcane mosaic virus (SCMV) is the predominant potyvirus associated with MCMV in causing MLN. The importance of vectors, including the maize thrips, was also determined as a contributing factor in the rapid emergence of this disease in Kenya. MCMV isolates from Kenya share a high degree of sequence identity, which has been helpful for diagnostic procedures, but there are at least two sequence groups among these isolates. Advances in resistance breeding, a critical component in the long-term control of MLN on smallholder farms in east Africa, are also discussed.

In the second article, Sudarshana et al. (2015) describe a new disease currently threatening the grapevine industry. The disease is aptly named "red blotch" for the characteristic red blotches that appear initially on the basal leaves in late summer/early fall that extend to middle leaves of the shoots as the disease progresses. The most significant effect of the disease is the reduction in total soluble solids in the fruit juice from symptomatic vines. In this paper, the authors describe the differential symptom expression among the red and white grape varieties, the identification of a virus named Grapevine red blotch-associated virus $(\mathrm{GRBaV})$ in diseased grapevines, the development of a PCR-based diagnostic assay, and the characterization of the North American population of the virus.

And lastly, Roy et al. (2015) provide a fascinating account of citrus leprosis, a disease that was first reported in Florida in the 1860s. Though the disease caused extensive losses, it ceased to be a serious concern in Florida by the 1930s. The disease, however, re-emerged as a major threat to citrus production in South and Central America and is rapidly expanding its geographic range. Citrus leprosis is caused by a complex of viruses involving both cytoplasmic and nuclear viruses. All five viruses that have so far been identified are nonsystemic and cause only local lesions, but differ in their host ranges. These viruses 
are transmitted by mites in the genus Brevipalpus. In their paper, Roy et al. (2015) describe novel hosts for some of these viruses, new vectors within the genus Brevipalpus, and the replication of both cytoplasmic and nuclear viruses within mite species. This suggests the potential origin of these viruses in mite species, the crucial role of mites in disease transmission, and also the unique role of citrus as a vector of viruses and mites.

\section{LITERATURE CITED}

Cohen, Y., Van den Langenberg, K. M., Wehner, T. C., Ojiambo, P. S., Hausbeck, M., Quesada-Ocampo, L. M., Lebeda, A., Sierotzki, H., and Gisi, U. 2015. Resurgence of Pseudoperonospora cubensis: The causal agent of cucurbit downy mildew. Phytopathology 105:998-1012.

Fry, W. E., Birch, P. R. J., Judelson, H. S., Grunwald, N. J., Danies, G., Everts, K. L., Gevens, A. J., Gugino, B. K., Johnson, D. A., Johnson, S. B., McGrath, M. T., Myers, K. L., Ristaino, J. B., Roberts, P. D., Secor, G., and Smart, C. D. 2015. Five reasons to consider Phytophthora infestans a reemerging pathogen. Phytopathology 105:966-981.

Havis, N. D., Brown, J. K. M., Clemente, G., Frei, P., Jedryczka, M., Kaczmarek, J., Kaczmarek, M., Matusinsky, P., McGrann, G. R. D., Pereyra, S., Piotrowska, M., Sghyer, H., Tellier, A., and Hess, M. 2015. Ramularia collo-cygni-An emerging pathogen of barley crops. Phytopathology 105:895-904.

Kamvar, Z. N., Larsen, M. M., Kanaskie, A. M., Hansen, E. M., and Grünwald, N. J. 2015. Spatial and temporal analysis of populations of the sudden oak death pathogen in Oregon forests. Phytopathology 105:982-989.

Kelly, H. Y., Dufault, N. S., Walker, D. R., Isard, S. A., Schneider, R. W., Giesler, L. J., Wright, D. L., Marois, J. J., and Hartman, G. L. 2015. From select agent to an established pathogen: The response to Phakopsora pachyrhizi (soybean rust) in North America. Phytopathology 105:905-916.

Mahuku, G., Lockhart, B. E., Wanjala, B., Jones, M. W., Kimunye, J. N., Stewart, L. R., Cassone, B. J., Sevgan, S., Nyasani, J. O., Kusia, E., Kumar, P. L., Niblett, C. L., Kiggundu, A., Asea, G., Pappu, H. R., Wangai, A., Prasanna, B. M., and Redinbaugh, M. G. 2015. Maize lethal necrosis (MLN), an emerging threat to maize-based food security in sub-Saharan Africa. Phytopathology 105:956-965.

Mathew, F. M., Alananbeh, K. M., Jordahl, J. G., Meyer, S. M., Castlebury, L. A., Gulya, T. J., and Markell, S. G. 2015. Phomopsis stem canker: A reemerging threat to sunflower (Helianthus aпnииs) in the United States. Phytopathology 105:990-997.
Oliver, J. E., Cobine, P. A., and De La Fuente, L. 2015. Xylella fastidiosa isolates from both subsp. multiplex and fastidiosa cause disease on southern highbush blueberry (Vaccinium sp.) under greenhouse conditions. Phytopathology 105:855-862.

Olivera, P., Newcomb, M., Szabo, L. J., Rouse, M., Johnson, J., Gale, S., Luster, D. G., Hodson, D., Cox, J. A., Burgin, L., Hort, M., Gilligan, C. A., Patpour, M., Justesen, A. F., Hovmøller, M. S., Woldeab, G., Hailu, E., Hundie, B., Tadesse, K., Pumphrey, M., Singh, R. P., and Jin, Y. 2015. Phenotypic and genotypic characterization of race TKTTF of Puccinia graminis f. sp. tritici that caused a wheat stem rust epidemic in southern Ethiopia in 2013-14. Phytopathology 105:917-928.

Peterson, E. K., Hansen, E. M., and Kanaskie, A. 2015. Temporal epidemiology of sudden oak death in Oregon. Phytopathology 105:937-946.

Roy, A., Hartung, J. S., Schneider, W. L., Shao, J., León, G., Melzer, M. J., Beard, J. J., Otero-Colina, G., Bauchan, G. R., Ochoa, R., and Brlansky, R. H. 2015. Role bending: Complex relationships between viruses, hosts, and vectors related to citrus leprosis, an emerging disease. Phytopathology 105: 1013-1025.

Rush, C. M., Workneh, F., and Rashed, A. 2015. Significance and epidemiological aspects of late-season infections in the management of potato zebra chip. Phytopathology 105:929-936.

Sanatkar, M. R., Scoglio, C., Natarajan, B., Isard, S. A., and Garrett, K. A. 2015. History, epidemic evolution, and model burn-in for a network of annual invasion: Soybean rust. Phytopathology 105:947-955.

Singh, R. P., Hodson, D. P., Jin, Y., Lagudah, E. S., Ayliffe, M. A., Bhavani, S., Rouse, M. N., Pretorius, Z. A., Szabo, L. J., Huerta-Espino, J., Basnet, B. R., Lan, C., and Hovmøller, M. S. 2015. Emergence and spread of new races of wheat stem rust fungus: Continued threat to food security and prospects of genetic control. Phytopathology 105:872-884.

Sudarshana, M. R., Perry, K. L., and Fuchs, M. F. 2015. Grapevine red blotchassociated virus, an emerging threat to the grapevine industry. Phytopathology 105:1026-1032.

Thompson, S. M., Johnson, C. P., Lu, A. Y., Frampton, R. A., Sullivan, K. L., Fiers, M. W. E. J., Crowhurst, R. N., Pitman, A. R., Scott, I. A. W., Wen, A., Gudmestad, N. C., and Smith, G. R. 2015. Genomes of 'Candidatus Liberibacter solanacearum' haplotype A from New Zealand and the United States suggest significant genome plasticity in the species. Phytopathology 105:863-871.

Wyenandt, C. A., Simon, J. E., Pyne, R. M., Homa, K., McGrath, M. T., Zhang, S., Raid, R. N., Ma, L.-J., Wick, R., Guo, L., and Madeiras, A. 2015. Basil downy mildew (Peronospora belbahrii): Discoveries and challenges relative to its control. Phytopathology 105:885-894. 